Practices of place-making - globalisation and locality in the Philippines 


\title{
Practices of place-making - globalisation and locality in the Philippines
}

\begin{abstract}
Global flows of people and information in the Asia-Pacific region are creating new forms of place that stretch across national boundaries and rural-urban distinctions. These new mobile forms of place link long-inhabited rural areas to cities, national centres, and to rural frontiers within the nation. Here, we describe new forms of place that are being produced by contemporary migration and economic change, using data from the Philippines and applying Appadurai's (1995) theorization of translocality. Our analysis links these flows of overseas migrants to concomitant processes of economic change, migration and new rural livelihoods. We outline changing practices of place within the Philippines, exploring ways that transnational migration can articulate with apparently 'local' development and the flow-on effects from migration on the spatial patterns of rural livelihoods.
\end{abstract}

Keywords: migration, development, Philippines, livelihoods, place, translocality 
This paper is about place-making - the ways that people create a sense of place for themselves from networks of exchange, webs of affection and material landscapes. Our thesis is that migration and economic change, key features of globalisation, are producing new forms of local place, forms that sometimes extend across long distances and disparate topographies. To argue this case, we draw on data from community-based studies in the Philippines - the nation with the largest flows of overseas migrant workers in the global economy (Tyner and Donaldson, 1999:1). Our analysis links flows of Filipino migrants to work overseas with concomitant processes of economic change and migration within the Philippine nation. Though we being with communities in the Cordillera region of Northern Luzon, our analysis touches down in Hong Kong, Manila, and the plains of the Cagayan valley as we trace the place-making activities now extending indigenous villages through the Philippines and beyond.

\section{APPROACHING PLACE IN A GLOBALIZED CONTEXT}

In the burgeoning literature on globalization in geography (for a review see Kelly, 1999 and 2000), the meaning of terms such as place, community, and locality is not selfevident. Much research on place applies theorizations of globalisation that describe local people and places as caught up in global processes rather than as having agency in determining their engagements (see, for example, contributors to Bebbington and Batterbury, 2001). As Arturo Escobar (2001: 141) explains, in these approaches, the 'global' is usually mapped on to space, capital, history and agency while the 'local' is usually mapped on to place, labour and tradition. Critics of this approach (Gibson- 
Graham, 2003; Prazniak and Dirlik, 2001) argue that macro-level processes are constituted by, not constitutive of, actions and choices made at the local level. These authors assert that the nature of place may be changing with global movements of people and information, but place itself has not vanished. Clearly, more dynamic ways of thinking about transnationally connected places are required (Castree, 2004).

Our argument here thus engages contemporary concerns over the autonomy of place in the context of globalisation (Gibson-Graham, 2001; Massey, 1994; Prazniak and Dirlik, 2001). Unfortunately, many micro-level analyses of place either approach the local as determined by the global scale or do not build macro-micro links. We show here how the micro-level constitutes what appears to be the macro, thus addressing the problematic attribution of agency to abstract concepts such as 'global flows' in the literature on place. Escobar (2001:146) describes the typical narrative of globalisation as one where globalisation creates deterritorialised cultures and places. In these spaces, locality and community cease to be obvious, no longer inhabited by rooted or natural identities but produced by complex relations of culture and power. We take issue with this, along with Escobar, and show here how communities are reterritorialising in new forms, occupying virtual spaces and corridors, and continuing to produce new versions of rooted identities.

Concerns over economic equity and new livelihood strategies form an important part of our analysis. As Dirlik (2001: 38 in Prazniak and Dirlik) argues, the globalisation of the local doesn't compensate for the localization of the global, because of the unequal terms of exchange between local places and global markets. In our study sites in the Philippines, for example, cash income is required to access health care, education and transport. In the recent past, people have earned money through the simple-commodity 
production of temperate vegetable crops for the Philippine nation market. However, since ratifying the GATT Uruguay round (1994) and dropping tariffs on agricultural imports, farmers report that the national market has been flooded with less expensive temperate vegetables imported from China, undercutting their local produce (see Cordillera People's Alliance, 2004). Local farm-to-market transport and input costs, they claim, are higher than the cost of importing from China. The local response to this problem is often to shift the site of production and, by doing so, extend the 'local.' Here, we show how localities in the Philippines are addressing such inequalities of exchange with spatial strategies - mobility, migration, and opening new frontiers, negotiating globalisation across the porous boundaries of local forms of place.

Geography offers us several theorizations of place in which we can consider the problematic of producing locality in conditions of globalisation (see Castree, 2004, for a review.) Here, we are concerned with the relation between places as based in material constructs and locality as a structure of feeling. Massey has written about the porosity of place (1994), describing place and locality as being one and the same - an articulated moment in networks of social relations and understandings, one based on a situation of co-presence. Massey's idea of co-presence can be mediated by both face-to-face interaction and by long-distance contact, challenging the way we may think of places as enclosed by topographical as well as social boundaries. Technologies such as longdistance transport, mobile phones, internet, video, radio can all mediate the co-presence required for place-making, each producing new forms of locality and subjectivity. Appadurai (1995) offers a conceptualisation of locality where such technologies play a more explicit role in creating what he calls 'the translocal.' Thus, because the places we 
describe have forms of co-presence mediated by such technologies, we adopt Appadurai's ideas of locality to theorize our data. However, we do follow Massey in showing how the specificity of the new forms of locality we describe is derived not from mythical internal roots or isolation, but from the absolute particularity of the mixture of influences found in each 'site'.

We accept the premise that macro processes such as globalisation only take shape through the particular activities of people in place. But, following Dirlik (2001), we are conscious that agency is expressed within the limitations defined by particular economic situations, thus we have selected our empirical data to show the regional and global scope of actions for local agents. Our descriptions of new forms of transnational place are grounded in the specific experiences of local actors. These narratives of specific experience come from academic work engaging communities and civil society groups who are addressing the lived experiences of globalisation. To the stories of our respondents and our observations made in community-based development projects, we apply Appadurai's idea of translocality, aiming to extend Appadurai's theorization by building a typology of the new phenomena of translocal places.

\section{LOCALITY AND TRANSLOCALITY}

Appadurai (1995:204) theorizes locality as the key characteristic of place, defining it as a phenomenological quality, constituted by a sense of social immediacy, technologies of interaction, and the relativity of contexts. Locality is expressed in terms of agency, 
sociality and reproducibility, yet hard and regular work is required to maintain its materiality. For geographers, locality is the property that makes space into place. Locality emerges through a series of attachments and commitments that characterize local subjectivities. Locality is emergent from neighbourhoods, situated communities characterized by their spatial or virtual actuality and their potential for reproduction. Thus locality can be a property of both a 'traditional' or 'place-based' community and a 'virtual' internet-based community or a combination of both, such as a place-based primary site with a virtual aspect to its neighbourhood. Places and virtual neighbourhoods are not opposites; both must similarly generate and receive flows of information and value and be produced from, against, and in relation to extra-local contexts.

The concept of translocality (Appadurai, 1995:216) describes the complex conditions in which place-based neighbourhoods are created by both locals and circulating populations. This paper thus approaches place as relational or contextual, exploring how translocalities belong to specific cartographic sites, but are also un-grounded or 'virtual' or extend along complex nodes and pathways. The concept of translocality describes a space where 'economic' transactions and affective relations structure locality off the ground, as it were, but these transactions and relations nonetheless influence people's activities, social interdependence, and environmental sustainability in particular material contexts. Analysing communities as translocalities shifts the focus from the existing neighbourhood infrastructure, economy, and apparent livelihood strategies of the people present in a community to the network of absent members and flows of information and cash in which they are embedded. 


\section{A TYPOLOGY OF TRANSLOCALITY - PLACES AND HOUSEHOLDS}

All the localities discussed below are grounded in what are traditional upland terraced rice field farming systems of the Cordillera Central on the Philippine island of Luzon. In this region, traditional upland livelihoods involve multiple allocations of household labour to the production of rice in pond fields, sweet potato and legumes in shifting cultivation plots (swidden or kaingin), and the husbanding of chickens and pigs around houselots. This agricultural system is spread across several production niches located along a long slice of the montane ecology. In each of these niches the household labour force must again allocate labour to diverse tasks - maintenance or reproduction of a range of planting materials, production of organic fertilizers, maintenance or construction of at least two field types (pond field and swidden), production of animal feed, and husbandry of the animals themselves.

As the households engage with the cash economy to supply new needs, the pressure on the labour force escalates. Labour allocation is further complicated by the commitment of labour to education and to the cash economy. As the cash economy remains largely external to subsistence agricultural system, the community response tends towards the outward movement of labour and, eventually, the relocation of part of the community. This kind of migration has been noted elsewhere in Southeast Asia where it has caused both households and localities to become more 'spatially fragmented but socially embedded' (Rigg, 2001:93). This is an extension of work on earlier patterns of ruralurban migration (described in Ulack, 1996) where relations within the household were 
attenuated and neighbourhoods socially fragmented. Below, we explore three different patterns of spatial fragmentation in these 'traditional' rice-farming localities of the indigenous upland Philippines - Ifugao and Igorot communities on the Cordillera Central. Our sketches of these study sites illustrate how distinctive forms of sociality, reproducibility and agency characterize each expression of locality.

While it could be argued that locality, place and community have never been truly self-contained and self-evident and that histories of migration are much longer, certainly, in the late colonial period, the indigenous villages of Northern Luzon have come very close to meeting the stereotypical notions of the 'bounded village' of anthropology. Scott (1974) discusses the localising processes of Spanish and American colonial regimes on the Cordillera and the way in which colonialism ruptured previously strong ties between upstream and downstream communities. The lowland peoples became hispanicised and Christian, while the uplanders retained pre-colonial Filipino languages and customs. Identified as 'ethnic minorities' and distinguished from lowland Filipino society by language, dress and religion until well after Philippine independence in 1946,

Cordillerans rarely established communities outside the mountains. Until the late 1970s and early 1990s, outmigration from the Cordillera usually happened at the individual or household level.

Rural-overseas - OFWs remaking place in Asipulo, Ifugao

Asipulo is a village in the province of Ifugao, in the mountains of Northern Luzon. The village is classified as a 'cultural community' with members speaking one of several 
indigenous languages. ${ }^{1}$ People learn Pilipino and English, the national languages, through the school system, radio and print media. Approximately 14 hours from Manila, the town centre is accessible only by jeepney down a gravel road. There is no telephone service and electricity only arrived in 1996. Yet the indigenous Filipino people from this village understand themselves as world-travellers and global subjects, rather than 'tribal minorities' on the basis of their engagement in migration for contract work overseas.

During the period of McKay's research (1995 - 1997), destinations for female migrants from the Cordillera Administrative Region (CAR) in the northern Philippines varied. ${ }^{2}$ Circular migration for contract domestic work in Hong Kong and Singapore was the most common pursuit for Asipulo's Overseas Filipino Workers (OFWs). Other women the author met had travelled to 'Saudi' - the nations of the Arabian Gulf - as well as Taiwan and Malaysia. There were reports of women who had found contract work in factories in South Korea. As well, some women had gone to the Netherlands as 'au pairs' or to Canada, to work as 'Live-In Caregivers'.

In the 1994 households of Asipulo municipality, a sample of one neighbourhood (barangays Haliap and Panubtuban) suggested that approximately $2 \%$ of working age women were working on contracts overseas. ${ }^{3}$ Sixteen of one hundred sixty-seven households surveyed reported OFW remittances, often carried directly by friends or family every few months. Table 1 shows the locations of the women from these households.

Table 1. Locations of female OFWs from Asipulo 
OFWs remit money into their home communities through their families and this source of cash income reshapes livelihood strategies. OFW money is often invested in material goods - the construction and renovation of houses and stores, and the purchase of agricultural implements, cars and motorcycles. Returning workers bring appliances, clothing and toys as gifts. Remittances from overseas are used as capital for new commercial agricultural crops, particularly where men farm without the labour of female partners. Sometimes OFW money goes to buy supplies for starting up businesses such as a tailor shop or woodcraft shop for example. In Asipulo, respondents asserted that a neighbourhood with many workers overseas could be distinguished by the newness of its houses, cars, and exotic appliances, as well as commercial crops. Thus the circular migration of female OFWs to and from 'abroad' transforms rural landscapes in material ways. In Asipulo, the Asipulo-Hong Kong Benevolent Association (a group of Hong Kong-based workers) had recently funded the paving of the Municipal basketball court and renovations at the Municipal Hall (McKay 2003).

Groups such as the Benevolent Association emerge through the working conditions and translocal practices of migrants. Studies of overseas workers have documented how migrants living and working in private households encounter conditions that restrict their mobility and social contacts with locals (Mills, 2003), and can thus strengthen longdistance ties to family. Overseas, migrants tend to socialize with other migrants from their sending locality (Law, 2001; Constable, 1997, 2003). Though they make take successive contracts, communication and remittance practices continue and even intensify, rather than attenuate, social immediacy between migrants and sending localities (McKay, 2003). Overseas workers remit cash remittances, either through special 
remittance agencies or banks. They interact with their family and friends at home through technologies such as text messages, letters, phone calls, tapes, e-mail and videos. Migrant Filipinas also ship large boxes of household goods and clothes for redistribution at home. Relations between migrants and their households are mediated by these communications technologies, but also through actors such as remittance agencies, employment agents, banks and shipping firms.

Migration may open up new spaces of female freedom in sending neighbourhoods (McKay 2001, 2003). Remitting cash to family members can free migrant women from obligations to consult husbands and parents when it comes to decisions about their lives and work (McKay 2002,). Migrants may also keep some of their earnings for their own independent investments in education, further migration and small enterprises (Gibson $e t$ $a l, 2001)$. Dependent households can resent these 'diversions', claiming a right to the migrant's full salary on the basis of her gendered maternal or filial duty (McKay, 2004.) Thus households interpellate migrants, but migrants also use the experience of migration and their savings to become other kinds of subjects - investors, politicians, and citizens. While migration may create newly legitimate claims for women to inhabit previously masculine civic and economic roles, the issue of the power to request, direct, claim and distribute remittances simultaneously reveals tensions over gender roles in the mesh of household relations. Along with these economic changes come new kinds of emotion,, forms of subjectivity and new cultural practices.

When it comes to local livelihoods, in Asipulo remittances are invested to change subsistence agricultural systems to less sustainable commercial cash crops, replacing pondfield rice with input-intensive vegetable crops and abandoning upland shifting 
cultivation fields (McKay 2003). The absence of women intensifies the work of husbands and extended families, creating new masculine roles, relations and forms of knowledge for men who share the parenting of children with a long-distance partner/breadwinner, rather than a 'traditional wife'. Migrants and their partners must renegotiate their norms for interaction and expectations of each other around remittances, investments, parenting and affection. Meanwhile, predominantly this female circular migration also changes the local landscape in terms of discourses on gender and labour. Rural families use remittances to invest in cultural capital through spending on weddings, funerals and education. Sending other family members to urban schools for post-secondary training is one of the remittance goals of many OFWs. This produces a second flow of young people, predominantly women, from rural to urban areas in pursuit of education. Ironically, education often leads to new rounds of migration when new graduates find themselves un- or under-employed. Many female graduates are unable to find a job commensurate to their qualifications in their home community or in Philippine urban centres. Some choose to take contract domestic work overseas, leaving husbands and children to join friends or siblings working abroad. In Asipulo, it seems there is always someone going 'abroad,' someone working there to receive them, and someone on the way back home to bring news, money and gifts. Circular migration thus produces translocalities; it creates one community that can imagine itself as circulating in an imaginative hyphenated space of Asipulo-Hong Kong.

Seeing other communities and households funding the good life through female outmigration, local people imagine their own versions of 'abroad'. Many non-migrants themselves would like to have the option of leaving for elsewhere. They envy those 
women overseas who send home gifts to earn the gratitude and respect of family and friends, returning only briefly as glamorous visitors. These imaginations have their impacts on Asipulo as a community. The production of locality 'requires the continuous construction, both practical and discursive, of an ethnoscape (necessarily non-local) against which local practices and projects are imagined to take place' (Appadurai, 1995: 209). In Asipulo, the local understanding of femininity, migrants and migration construct this ethnoscape. Through migration, people are redefining the lived meanings of 'place' Asipulo is now structured as and imagined to be a translocality (McKay 2001). The community occupies a space of circulation between Ifugao and Hong Kong. Both OFWs themselves and their community's imaginative constructions of them both move through material places and imaginative hyphenated spaces, layering each on top of the other until the boundaries that might separate them blur. The material landscape and cultural norms of Asipulo emerge from both social and economic relations and imaginative suppositions in all these sites. Asipulo, as a primary or 'sending' neighbourhood, becomes seen as a site for the reproduction of skilled workers in a global labour market.

In Asipulo, locality is constituted by OFW groups, such as the Asipulo-Hong Kong Benevolent association, and maintained through techniques of text, e-mail, letters, visits and recruiting and the sending/receiving of remittances. This form of locality is established against the ethnoscape of the Hong Kong labour market. In Hong Kong, Ifugao migrants join the ranks of 'Filipinas', choosing not to identify as 'ethnic' even as they maintain their own locality-produced social networks (McKay 2001). Asipulo people express their entitlements to translocal spaces are through rhetorics of skills and education. Respondents asserted that, since Ifugao people learned English under the 
American colonial administration, they enjoyed preferential access to the better jobs in the Hong Kong domestic labour market (see Luz's story in Gibson, Law and McKay, 2001). Since Asipulo people can market their language skills as social capital in Hong Kong, they can also consider themselves appropriately educated and 'worldly' agents of development when they move into the agricultural frontier areas of the Cagayan valley (for further discussion, see McKay 2001 and below).

Comment [S1]: finish

Rural-urban-Bayyo, Mountain Province

Like Asipulo in Ifugao, Bayyo is a 'classic' Cordillera upland settlement in which pond field rice has dominated the landscape and economy, supplemented by upland swidden production of sweet potato and shorter-term crops of beans. At present, rice production continues, supplemented by intermittent daily wage labour, but outmigration and government employment are the major economic arenas. ${ }^{4}$

An overview of the economic positioning of households in Bayyo, Mountain Province ${ }^{5}$ articulates with the findings from Asipulo - Bayyo is involved in a different form of translocality. In 1989, the Rural Health Unit of Bayyo listed 138 households including absentees. In 1997, 180 houses were counted, 140 of them occupied and most of these old structures that have been repaired and renovated. Few new houses have been built in Bayyo since 1960. The majority of the occupants consist of couples between 50 and 70 years old with a few children of elementary school age in their care. 
As of 1997, the Rural Health Unit lists 10 childbearing women in the settlement. There were 80 elementary school children in Grades 1 through 5 and not enough children to justify opening a $6^{\text {th }}$ grade.

Outmigration has drained Bayyo of most of the productive population segment. These outmigrants have established their own permanent residences in Baguio City, Benguet Province and in Metro-Manila where their children are raised and schooled. According to John Lattip, Bayyo-born but non-resident, who sustains contacts with many migrant communities, there are more Bayyo people in Manila than in Baguio City, more in Baguio than in Bayyo itself, and others of Bayyo origin in Kalinga, Ifugao, and Quirino provinces.

While outmigration of individuals for employment or marriage is now common throughout the Cordillera, the Bayyo case is an instance where a much larger contingent of community members has made a shift to one or two sites outside the mountains .This shift was mainly due to the rapid development of a jeepney manufacturing industry that began with one business started by a Bayyo migrant to Manila. By 1997 there were six major jeepney fabrication yards owned by Bayyo families in Manila. These industries have spun off steel fabrication, automotive mechanics, jeepney operation and various types of related and supporting employment that engage additional migrants from Bayyo. For instance, Bayyo migrant-made jeeps and drivers transport forest products (like sphagnum moss) harvested in the environs of Bayyo to Manila garden shops.

Bayyo people call the space of outmigration layasan, roughly translatable as 'the distant destinations of those who have moved away'. ${ }^{6}$ Layasan is a conceptual unit of internality extended into the external. From conversations with Bayyo residents one 
might infer that the layasan is composed of cultural satellites - if not tributary colonies of Bayyo. This must be understood, at first reading, in terms of the traditional mode of identification of persons in the Cordillera. They are identified not by ethnicity or culture area but by place of birth and residence. One is named such and such and is defined as of a particular place - e.g. John Lattip i-Bayyo, 'of Bayyo'. In enclaves of people claiming Bayyo identity, or taga-Bayyo (Bayyo people) the traditions, affiliations, and mutual support networks of and with the home nucleus are maintained, or at least consciously asserted. Layasan can thus be read as synonymous with Appadurai's translocality.

Practices of sociality sustain the layasan. Seasonally, for major national holidays, for the rice planting and harvest, and the subsequent planting of sweet potato in the dry vacated pond fields, the migrant Bayyo flock home. Weddings and funerals engender a constant flow of traffic between Bayyo and its satellites. The younger cohorts of the migrant population, in many cases speaking the national language rather than the Bayyo language, are said to seek the counsel of Bayyo elders and to use new forms like neighbourhood associations to maintain solidarity with others of Bayyo affiliation.

Seasonal homecomings are the occasions for layasan households to withdraw their share of the 'good' local variety rice for their use in the urban locale. The productivity of Bayyo rice fields has its own translocal aspects. The Bayyo locale continues to provide and reserve, in home granaries, the preferred traditional variety to maintain the quality not necessarily the quantity - of staple consumption for the layasan households. Custom dictates that the home granaries are never emptied, and the layasan shares never depleted, even if the Bayyo rice producer must supplement the home-grown stock with commercial rice of inferior eating quality. 
Bayyo residents claim that most households have adequate pond field holdings to allow maintaining a granary for each absent member. These absent members return to assist in the maintenance of the rice production cycle and also send back supplies of tinned goods, coffee, sugar, flour and household appliances for the ageing parental household. The condition appears to be in temporary balance, dependent on the sustainability of the dwindling Bayyo stock of resident human resources.

Labour outflow has left the community with a deficit in human energy. The traditional agricultural system shows the impacts of the deficit. But sustained relations with the layasan mitigate these impacts in some respects. Rice production is sustained by seasonal labour inflow from the satellites and intermittent hired labour paid for with externally generated revenues. Some pond rice fields have either been allowed to revert to dry fields (katuwalli) for sweet potato and short term vegetable crops or seconded to households with labour supply and no pond fields of their own.

The same labour outflow reflects the absence of enabling factors for diversification that would engage human energies and locate them in a productive local setting. A semipermeable membrane has been established between Bayyo and the world of the Pilipinospeaking, Manila-focussed 'national mainstream'. Through this membrane information and materials have passed selectively. Both production alternatives and the development of markets have been stunted by the relationship to external goods and to opportunities for education and employment, as the Philippine national pattern of centralized economic and political growth has produced pressure for inward flow of commodities and outward flow of a few local materials and many personnel. It is rational within such a context that 
investments into diversification or expansion of the economic life of Bayyo, considered as the settlement marked on the map, do not occur.

Instead the economic space of Bayyo has been reconstructed elsewhere. This move has been made in response to constraints on the capacity of the place-based indigenous economy to support and engage a growing labour potential. Production of a marketable food surplus from within the indigenous Bayyo agricultural system would pressure land and forest resources. Place-based diversifications into local non-agricultural engagements come in the form of limited opportunities in local government, daily wage work on government construction projects, or agricultural commodity trading in an arena overcrowded by many local communities in similar circumstances. All this was occurs even as the need for cash - for education, for health care, for legal services or exercises in governance or political participation, and for commercial goods - is rapidly increasing.

Bayyo is a unique case of relocation. The existence of the translocated community hinges on an entrepreneurial twist of fortune that started off the first Bayyo jeep manufacturing shop in the layasan. This historical anecdote was recounted to Brady by the barrio captain of Bayyo in 1997. ${ }^{7}$ As Brady recalls the story,

Edson of Bayyo had been jobless in Manila for a few months and contacted his village-mate Joseph for a survival loan, one in a series of similar requests from other Cordillera people working in Manila. Joseph scolded Edson for this 'begging' which was not culturally acceptable for someone from Bayyo. Joseph was working as a mechanic in a jeep fabrication shop and secured a place in the shop for Edson to train as a welder. In a few months, with skills and cash investments from relatives, the pair built their own jeep, sold it, and before long were in 
business for themselves, selling jeepneys to Cordillerans with savings from overseas and domestic employment. They employed village-mates in the growing fabrication business, in the spin-off jobs as drivers and driver helpers for Manila jeepney routes, as maintenance mechanics and so on.

Here, in translocal Bayyo, according to Brady's respondent, entitlements to translocal spaces are expressed through the assertions of skill and self-employment - developing new products to meet the needs of a growing national transport market.l. As the industry Comment [S2]: ? invited more Bayyo manufacturers, the Manila-Bayyo trips were a natural development, carrying a trade in Manila goods and Bayyo rice and forest products, and eventually bringing in families from Bayyo to settle into ready work and enabling the flow of visits back and forth. Bayyo jeepney profits and Bayyo labor soon built the concrete road that links Bayyo to the unsurfaced national road between Bontoc in the west and Ifugao in the east. The jeepneys are now the physical means of translocality at several levels.

In the framework of returns to the idealized nucleus community and the exchange of goods, the history of Bayyo's economic orientation has established the translocality of the entire community. This translocality was made possible by the existence of an absorptive manufacturing complex established externally by members of the community who drew kin and neighbours into the sphere of new opportunity. Bayyo people now reproduce the conditions and relations for dynamic economic capacity elsewhere.

Sustaining ties between migrants and the primary site of the community in more than just a virtual sense (at least for the interim) is only been possible because the migrants have relocated within the nation, within the same island of Luzon. Communication through the relatively inexpensive and accessible mobile phone technology is a 
significant aspect of sustaining ties. Another important feature of this translocality is the happy coincidence of participation, as a translocal community, in a transport industry that materially accesses the outside world of opportunity and also physically carries the spatially diversified segments home. The physical Bayyo itself, for those in the layasan, exists as a vacation place, a refuge where cultural identity is reproduced and reaffirmed. On the map, the space labelled Bayyo is becoming a locus of reference rather than of residence.

Why Bayyo is sustained is evident in the discourses on the nature of home and identity and, indeed, of the nature of social being. How it may continue to be sustained, even as a place of retirement for ageing returnees is not so clear, even in the conversations among the elderly men who rarely enjoy the attention of young replacements in the empty spaces of the village council site. Bayyo, Mountain Province, is the stuff of which legends and myths of origin might someday be made.

In Bayyo, locality is constituted by long-distance transport links - jeepneys that are Bayyo-layasan owned, built and driven - and resource extraction. The ethnoscape against which Bayyo is defined is the Manila-Baguio urban transport network where ethnic disidentification has Bayyo people joining the urban working/middle class as selfemployed entrepreneurs and their wage labourers. Bayyo people are becoming 'Filipino' jeepney drivers first and then, only secondarily, taga-Bayyo, on the streets of Manila's urban sprawl.

Rural-rural - spill-on effects from Types 1 and 2 - Isabela 
Returning to Asipulo, Ifugao, the influx of capital from OFWs is creating other flow on effects. Asipulo is already short of arable land to accommodate a growing population and OFW investments, by converting pondfields from rice to vegetables, have created additional land scarcity. Here, as in Bayyo, people respond to economic transformations, reworked divisions of labour, and shortages of land with outmigration. While female migrants are working overseas, their households and neighbours are opening up agricultural land by 'pioneering' in nearby provinces. New settlements on the agricultural frontier occupied by migrants from Asipulo are shown in Map 1. These dispersed sites are important for flows of resources, people, production and knowledge and the organization of household labour, and these processes, in turn, are creating new forms of social stratification within the primary Asipulo community.

Map 1. Inter-regional migration from Asipulo to the Cagayan Valley

People in fifty-three percent of the households surveyed in Asipulo reported that immediate relatives (parents, children or siblings) had 'transferred' to these relatively nearby rural areas. The most frequently mentioned sites were in the municipalities of Kasibu, Nueva Viscaya, Cordon and San Mariano, Isabela, and Maddela, Quirino. Another eighteen percent of respondents reported relatives in urban areas including the provincial capital of Ifugao (Lagawe), the municipalities along the National Highway (Bayombong and Solano) in Nueva Viscaya, as well as Baguio City, and the greater Manila area. Figure 1 details the prevalence of remittances to Asipulo households from areas outside the municipality. Of the households surveyed, people in seventeen percent of the sample reported income remitted to Asipulo in cash or kind by kin who had 
migrated. Five percent of the households had income from outmigration sites, ten percent from family members working overseas and two percent from professionals working in urban areas.

Figure 1. Households reporting income from out-of-province, by source of income, Asipulo (1996) (n=167)

Unlike the rural-urban migration of Bayyo, rural-rural outmigration was the predominant strategy reported in Asipulo. Many respondents asserted that when their children inherited their lands, on marriage, they would 'transfer' to another place. Opening new land for commercial crops is a high risk/high return venture but a necessary one, due to the shortage of irrigated rice land in Ifugao. These respondents often mentioned locations where they planned to join relatives farming in areas found along the lowland 'agricultural frontier'. This frontier has been opened up in spaces where commercial logging interests have built roads into previously inaccessible and forested areas. These places tend to be ethnically mixed and politically fractious, with active New People's Army (communist guerrilla) cadres and militarisation. Asipulo people explain their entitlements to land on this frontier through rhetorics of pre-Hispanic inhabitation and their activities as agents of the civilizing religious state. As educated and Christian people, they are 'improving' the land by bringing it into production.

Resources and people flow back and forth between households farming in both sending and outmigration areas. Out-migrants frequently send their children back to relatives in Asipulo for high school education. Unemployed Asipulo youth find room and 
board in exchange for their labour in the outmigration sites. The flows of labour between Asipulo and rural out-migration sites tended to be made up of young men, while their female counterparts were more likely to be in urban areas or overseas. Migrants from Asipulo settle with other Ifugao speakers in outmigration areas, preferably fellow speakers of the Ayangan Ifugao dialect and likely kin.

Security of tenure in outmigration areas is usually even more insecure than it is in Ifugao Province proper, with all but the commercial rice areas of Isabela Province described as 'squatted' or 'pioneered'. Outmigrants begin by making swidden fields, but integrate swidden into the production of fruit and vegetable cash crops or commercial rice for the national market, rather than combining it with subsistence rice cultivation as in the traditional agricultural system of Asipulo. In outmigration sites, shifting cultivation is seen as a temporary backstop - a step in supporting the 'real work' of commercial farming and a recognized way of 'claiming' land.

Community tenure over forest areas, a feature of Ifugao customary law, does not hold in ethnically mixed outmigration areas where individual private property is the norm. Making swidden fields is the primary way of 'improving' and establishing permanent claims to parcels of land intended for eventual commercial production. The strategy for 'pioneering' is to enter an area that has previously been selectively logged as a timber concession, and then find suitable soils and plots with access to a logging road. Here, Asipulo migrants are not integrating swidden into their indigenous rice-cropping system, but acting as 'peasant migrants', attempting to create small-scale vegetable and fruit farms linked directly to national markets. Thus, the peasant migrants and indigenous 
integral swiddeners are members of one community, farming in different sites under different sets of 'rules' (as described by Warner, 1991: 9-11).

In Asipulo, the respondents classified, loosely, as upper income households (approximately twenty-two percent of those surveyed) with lands outside the province (four percent of that sample) almost all own parcels of commercial rice fields. Not only did these wealthier families describe their relationship to their lands outside the province as 'owned' rather than 'squatted,' many of them had tenants. These tenants were poorer relatives or clients from their Asipulo neighbourhood. Tenants cleared swidden fields to supplement their income and assure their food security. Tenant families reported frequent moves between their Ifugao home and outmigration areas as they scraped together marginal livelihoods. In contrast, wealthier households reported more immediate family members living and working in urban areas, usually as professionals in Baguio City and Manila. The twelve percent of sample households reporting regular cash remittances from urban areas belonged to the upper-income group, while the tenants were all in the lowerincome group. It is clear that urban, and in many cases, overseas remittances provided or added to the capital available for wealthier households to invest in these tenant-operated lands.

McKay collected narratives that illustrate how remittances from overseas workers supply the capital to allow middle-income rural families to make this kind of translocal move as part of a diversified economic strategy. For example, Luz, interviewed in 1998 by McKay (see Gibson, Law and McKay 2001) explained how she bought one hectare of riceland from under-capitalised farmers in San Mateo, Isabela, an Asipulo outmigration area some distance from her barangay. Luz arranged to have this land farmed by distant 
relatives who moved to the ricelands to become her tenants. These fields produce three harvests of rice per year. ${ }^{8}$ She has also taken a mortgage on rice fields elsewhere in Ifugao that she intends to buy, but will not farm herself. Though she grew up in an agricultural household and farmed rice in her youth, Luz is, as a returned OFW, part of the local elite. Her activities are non-agricultural. She has purchased a jeepney and autorepair business for her husband. To keep her 'busy,' Luz has opened a small store alongside her house - a sari-sari - where she sells imported canned goods, imported clothes, and jewellery.

In the rural frontier settlements, people like Luz visit periodically to oversee harvests or planting. In translocal Asipulo, a sense of social immediacy is produced through circulation via provincial bus networks of, such managerial visits, as well as the movements of farm labourers and schoolchildren and letters carried by the bus drivers. The translocal ethnoscape is framed by the ethnic composition of the rural frontier, where a variety of ethnic groups - - Ilongot, Ibaloy, Kankaney, Gaddang, Ibannag, and Ilocano are being recreated into a fractious 'Filipino peasantry.' If they choosing not to activate the ethnic identities of their originary communities, people can move away from their Ifugao identity to the more generalized identity of 'the rural poor' or kaingineros (shifting cultivators). In choosing not to identify as 'non-local' ethnic minorities, they may gain benefits from local governments and NGOs, rather than being told to return to their now distant 'home' villages where land is scarce.. Meanwhile, OFW investors like Luz, following the lead of the Bayyo people, may be moving the next generation of their households on to urban centres. 


\section{CONCLUSION}

It is easy to see the sign labelling the basketball court 'a project of the Asipulo-Hong Kong Benevolent Association' as indicative of translocality. It is perhaps less easy to read Bayyo jeepneys in Manila or swidden farmers on the Cagayan Valley frontier as being translocal in their practice. Yet, in terms of their economic and social contexts, both urban jeepney drivers and rural swidden farmers can be seen as equally translocalised. As elsewhere in Southeast Asia and Asia, what might previously have seen as self-contained or self-supporting rural agricultural communities are increasingly becoming a 'make-work' project, nursery or retirement village for the dependents of migrants elsewhere and, ultimately perhaps, for aging migrants themselves (see Rigg, 2001, for examples from mainland Southeast Asia; Seddon et al, 2002, for Nepal). The new forms of off-farm livelihood that underpin this transition from local to translocal places are underpinned by local responses to the opportunities and constraints of national entry into global markets for commodities and services, such as the GATT (above.)

We have sketched three forms that translocality takes. In Asipulo, OFW groups and recruiting networks within the community are positioning local women as global subjects and migrant labourers. This produces a transnational form of translocality. In Bayyo, the layasan emerges from migrant self-employment and waged labour for others in processes of both ethnic disidentification and mobility. This is a national and urban form of translocality. Lastly, in the links between Asipulo and the rural, the circulation between the primary site and frontier locations reflects debts and investment of OFW money into 
land clearing or 'pioneering'. This is a national and rural frontier form of translocality, but one tied, directly and indirectly, to transnational connections.

As Escobar says (2001: 144) places have always joined together to form regions. Porosity of boundaries has always been essential to place-making. In our data, it is clear that the places we describe have shifted from being part of the Cordillera Region to being national and international in their connections. While still being 'of the Cordillera', they are equally becoming part of Hong Kong, part of the urban working class of Manila, and part of the rural frontier. Considering the porosity of place (Dirlik, 2001: 42 and Massey, 19934), porous relations seem to be negotiated along different axes here. While labour flows out of the primary community sites, outsiders are not flowing in. Both Asipulo and Bayyo are closed communities and outsiders are not entering except by marriage.

Porosity of boundaries is not the same as their abolition. Thus, in these primary sites the maintenance of ethnic identities and rules for land tenure create new forms of locality that are place-based, but not place-bound.

As agents of translocality, migrants have engaged the opportunities available for persons with limited capital and skill available in areas outside their sending community. Their communities, in turn, have remained peripheral to large-scale commercial employment or investment options. In the broader pattern of Philippine development, the locus of economic development has been in urban areas and 'special economic zones'. This has led towards the gradual commercialisation of agriculture within peripheral places and their recasting as sources of raw materials or labour. While labour and raw materials flow outwards, consumer goods and services flow in, creating an increasing economic pressure within the sending neighbourhood. The tendency is for labour to move 
towards spaces where opportunity can be constituted and appropriated. We have shown here how these spaces are not uniformly urban or national, but can also be international or rural.

Globalisation here is emergent from the actions of people with different forms of control over space. In the space Cordillerans do control - that of their originary village people have different levels of access to the means of production, to skills and to technologies. People in Bayyo or Asipulo, for instance may own land, but may not have the skills or technologies to reduce farm-to-market costs or produce value-added products. Instead, they choose to extend their communities spatially. Translocality is thus response where people appropriate available space elsewhere and make it productive, connecting that productive space to the primary neighbourhood site. These connections allow the originary neighbourhood to exceed topographic boundaries that would otherwise grow confining. The apping of the economic landscape with production and consumption locii brought about by national and regional interpretations of globalisation (see Kelly, 1999 and 2000 for examples) and the cultural vocabulary of motives for mobility outlined here channel the forms taken by translocality.

These three forms of translocality may be fleeting. Appadurai's (1995) neighbourhoods are actually existing social forms in which locality is variably realised Thus, each of these translocal 'sites' will have varying degrees of locality that may waver over time. Translocality as a development strategy may prove to be limited in its effectiveness. The Bayyo jeepney marks this limitation. A jeepney is a relatively smallscale investment, an affordable exchange for moderate OFW earnings. It is likely to require support from other networked engagements of migrant households whose 
offspring will undoubtedly access other urban opportunities for diversification out of the industry and out of the Bayyo neighbourhood. Likewise, the fields purchased or opened up in an outmigration area mark another limitation. They reproduce the agricultural engagement of the primary community, expanding boundaries and moving the community from subsistence to commercial production of rice and vegetables. However, farming remains within a sphere of agriculture that receives little attention from successive Philippine governments focussed on technical competitiveness and export revenues in their response to the constraints and opportunities of globalisation (Kelly, 2000). The extensions and transformations of sociality here, the layasan and the tenancy relations and the OFW associations, reflect a creative and judicious manipulation of personal and communal resources under conditions of translocality. In cases where the pressures of familial and community obligation have dissipated the revenues from multiply-tasked OFWs, the tenuousness of these rearrangements is most clear.

Returning to Escobar's description of globalisation, we have shown how our three forms of translocality are not delocalised, disembedded and caught up in universalised modes of economy, culture and thought. Instead, they are places of a new and different sort. These villages are communities shifting from place-bounded localities to more 'virtual' neighbourhoods, while still remaining anchored in an originary place. Bayyo provides a good example of how the spatial transformation occurs without disturbing a sense of originary identity. In terms of local identities and subjectivities tied to place, $i$ Bayyo (of Bayyo) and taga-Bayyo (Bayyo person) used to mean the same thing. Now, be taga-Bayyo does not mean that you have to have been born in or live in Bayyo. Someone who is taga-Bayyo may be born and live as part of the layasan, but still be a Bayyo 
person. In this very local way, through this kind of extended identification, people in the

Philippines are practicing the local in the global (Friedman 1997:176 in Escobar, 2001:

147).

\section{ACKNOWLEDGEMENTS}

The authors would like to thank their respondents in Asipulo, Bayyo and the layasan of each site. At ANU, Sandra Davenport provided assistance with formatting, editing, tables and maps.

\section{NOTES}

1 'Cultural community' is the official Philippine government designation for the 'tribal' communities of the indigenous northern Philippines. See

http://www.ncca.gov.ph/phil._culture/ncca-people.htm under the Ifugao link for a listing of the 'Northern Cultural Communities' into which the Ayangan-speaking Ifugao people of Asipulo municipality, Ifugao province can be mapped. The Cordillera Autonomous Region (CAR) is the group of northern Philippine Provinces that are the traditional lands of these Northern cultural communities.

${ }^{2}$ McKay was working on an ethnographic study of women's changing roles in agriculture in Ifugao in 1996 - 1997. She became interested in migration through the number of respondents going overseas and the evident influence of remittances on local economies. Her research on community history (McKay, forthcoming) in her Asipulo study site took her to outmigration sites to interview elders who had left the community. Data presented here draw on household surveys (see McKay 2003), semi-structured and openended interviews (McKay 2001, 2002) on agriculture, gender roles and community history.

${ }^{3}$ In less remote areas of the northern Philippines, some communities are more strongly shaped by female out-migration. In the Ilocos, one village surveyed had thirteen percent of the adult working population overseas, with seventy percent of those migrants female, and sixty-two percent of households reporting migrant workers (Pertierra, 1994:67).

${ }^{4}$ The data for this section of the paper draw on studies conducted in Bayyo in 1993 to 1994 by Rosanna Mula and Ma. Luz D. Fangasan and in 1997 by Betty Gayao, Jovita Sim and Carol H.M. Brady. The studies were supported by grants from the User's Perspective with Research and Development (UPWARD-CIP). For this paper, Brady revisited Bayyo in 2003 and did informal interviews with Bayyo jeepney drivers and owners at UP Diliman and in Baguio City.

${ }^{5}$ Bayyo is a settlement (barangay) of Bontoc Municipality in Mountain Province, at the heart of the Cordillera Central mountains of Northern Luzon, Philippines. The settlement lies southeast of Bontoc and is accessible from Bontoc Central town in 1 to 2 hours travel (depending on the season) over unsurfaced roads .

${ }^{6}$ For example, a $i$-Bayyo person might say of Quezon City in Manila, 'ijay ti layasanmi,' (our farness is there).

${ }_{8}^{7}$ Brady has reconstructed this from her fieldnotes and translated it from the original Ilocano.

${ }^{8}$ Average Ifugao households need about .25 ha of riceland to be self-sufficient in hybrid rice with two harvests per year (Guy, 1995). This cost Luz approximately \$ 4200 (NZ) 
and produces 6 times the average household needs over the course of the year. Owning this field gives Luz one third of each of the three harvests, or twice average household requirements.

\section{REFERENCES}

Appadurai, A. (1995) The production of locality, in R. Fardon (ed.), Counterworks: Managing the diversity of knowledge, pp. 204-225. New York: Routledge.

Appadurai, A. (1996) Modernity at large: Cultural dimensions of globalisation. Minneapolis: University of Minnesota Press.

Bebbington, A. and S. Batterbury (2001) Transnational livelihoods and landscapes: Political ecologies of globalisation, Ecumene 8(4): 369-380.

Castree, N. (2004) Differential geographies: Place indigenous rights and 'local' resources, Political Geography 3:133-167.

Cordillera People's Alliance, 2004. Cordillera agri situationer, July 31, 2004. http://www.cpaphils.org/campaigns/cordi_agri-sit_4731.htm\#impact

Constable, N. (1997) Maid to order in Hong Kong: stories of Filipina workers. Ithaca:

Cornell University Press.

Constable, N. (2003) A transnational perspective on divorce and marriage: Filipina wives and workers. Identities: Global Studies in Culture and Power 10: 163 - 180.

Dirlik, A. (2001) Placed-Based Imagination: Globalism and the Politics of Place, in R. Prazniak and A. Dirlik, Places and politics in an age of globalisation. New York: Rowman and Littlefield.

Escobar, A. (2001) Culture sits in places, Political Geography 20:139-174.

Gibson, K., L. Law and D. McKay (2001) Beyond heroes and victims: Filipina contract migrants, economic activism and class transformation, International Feminist Journal of Politics, 3(3): 365-386. Gibson-Graham, J.K. (2003) An ethics of the local, Rethinking Marxism, 15(1): 49-74.

Guy, P. ed. (1995): Agroecosystem analysis and rapid rural appraisal of selected sites in the Central Cordillera, Ifugao, Philippines. (Halifax, Nova Scotia: Environment and Resource Management Project.)

Kelly, P. (1999) The geographies and politics of globalisation, Progress in Human Geography 23(3): 379-400.

Kelly, P. (2000) Landscapes of globalisation: human geographies of economic change in the Philippines. (London: Routledge)

Law, L. (2001) Home cooking: Filipino women and geographies of the senses in Hong Kong, Ecumene 8(3): 264-283.

Massey, D. (1994) Space, place and gender (Cambridge: Polity Press).

McKay, D. (2001) Migration and masquerade: Gender and habitus in the Philippines, Geography Research Forum, 21: 44-56.

McKay, D. (2002) Negotiating positionings: Exchanging life stories in research interviews, in P. Moss (ed.) Feminist geography in practice: Research and methods, pp. 187-199. London: Blackwell Publishers. 
McKay, D. (2003) Cultivating new local futures: Remittance economies and land-use patterns in Ifugao, Philippines, Journal of Southeast Asian Studies 34(2): 285-306.

McKay, D. (2004) Dutiful daughters abroad: globalization and the Philippine transnational household. Gender, place and culture (in press).

Mills, M.B. (2003) Gender and inequality in the global labor force, Annual Review of Anthropology, 32: 41-62.

Pertierra, R. (1994) Lured abroad: The case of Ilocano overseas workers, Sojourn 9(1): 54-80.

Prazniak, R. and A. Dirlik (2001) Places and politics in an age of globalisation. New York: Rowman and Littlefield.

Rigg, J. (2001) More than the soil: Rural change in Southeast Asia. Harlow, UK: Pearson Education Limited.

Scott, W. (1974) The discovery of the Igorots: Spanish contacts with the pagans of Northern Luzon (Quezon City: New Day Publishers)

Seddon D. with J. Adhikari and G. Gurung (2002) Foreign labor migration and the remittance economy of Nepal, Critical Asian Studies, 34(1): 19-40.

Tyner, J. and D. Donaldson (1999) The geography of Philippine international labor migration fields, Asia Pacific Viewpoint 40(3): 217-234.

Ulack, R. (1986) Ties to origin, remittances and mobility: evidence from rural and urban areas in the Philippines, Journal of Developing Areas 20: 339-356.

Warner, K. (1991) Shifting Cultivation: Local technical knowledge and natural resource management in the humid tropics. Rome: Food and Agricultural Organisation. 
Table 1 Locations of female OFWs from Asipulo

\begin{tabular}{|l|c|}
\hline Location of Employment & No. of Individuals \\
\hline Hong Kong & 8 \\
\hline Singapore & 3 \\
\hline 'Saudi' & 2 \\
\hline Taiwan & 2 \\
\hline Malaysia & 1 \\
\hline
\end{tabular}


Map 1. Inter-regional migration from Asipulo to the Cagayan Valley and (from Bayyo to Manila to be added to a larger map when Cartography can assist)

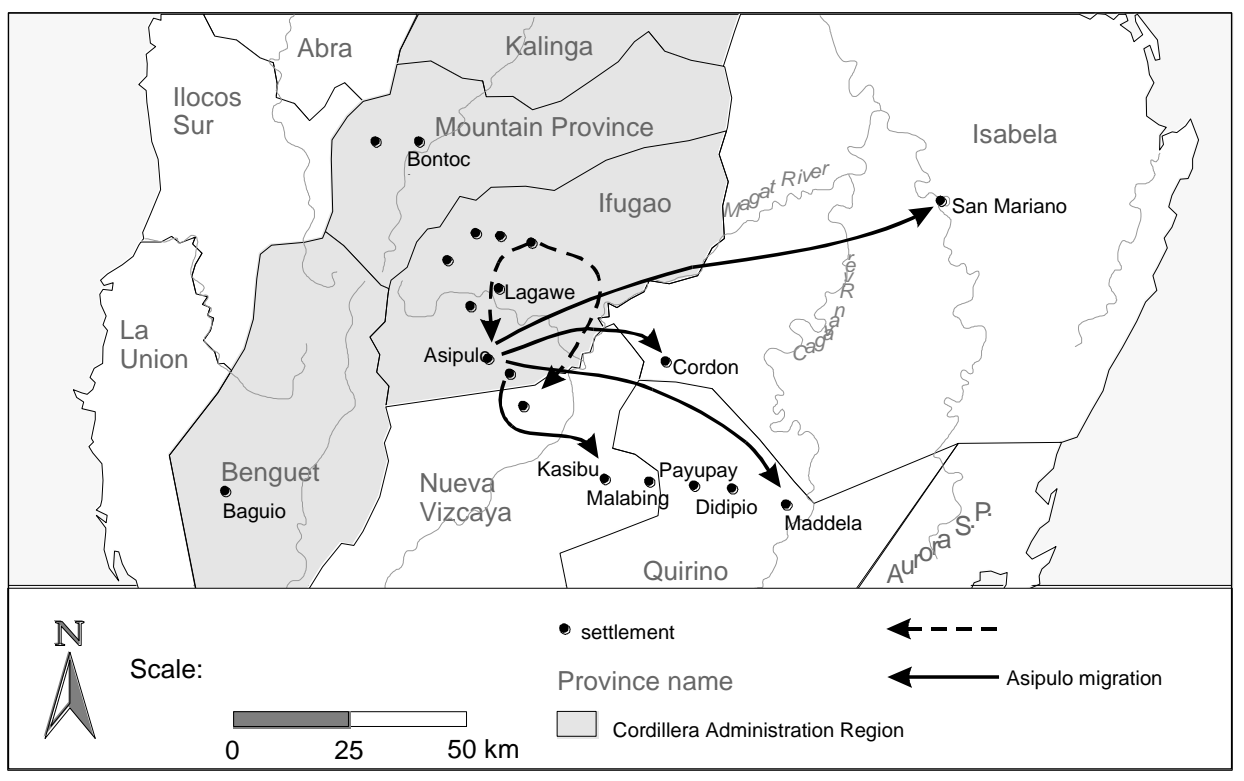


Figure 1. Households reporting income from out-of-province, by source of income, Asipulo (1996) $(\mathrm{n}=167)$

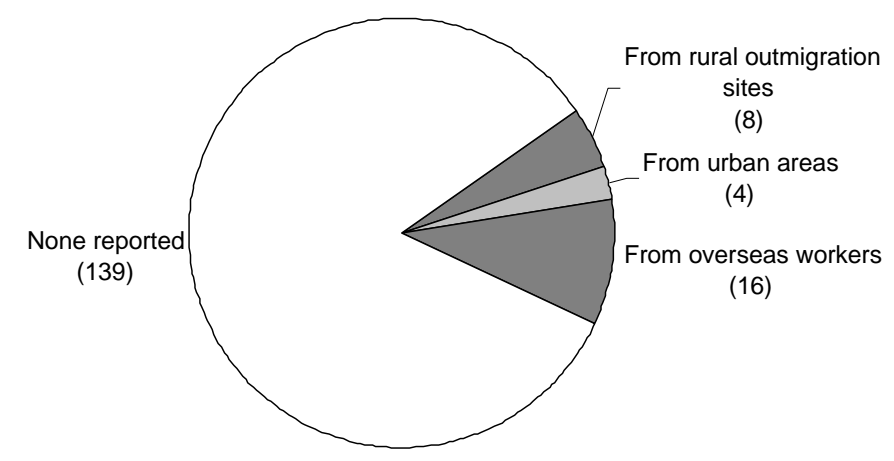

